\title{
INTERPRETATION OF THE EIGHTH \\ AMENDMENT-RUMMEL, SOLEM, AND \\ THE VENERABLE CASE OF \\ WEEMS v. UNITED STATES
}

In the past four years the Supreme Court twice has faced cliallenges to life sentences mandated under state recidivist statutes. In Rummel v. Estelle the Court upheld a life sentence which was triggered under the Texas recidivist statute by the crime of obtaining money by false pretenses. Three years later, lowever, the Court in Solem $v$. $\mathrm{Helm}^{2}$ reversed a life sentence which was imposed under a similar South Dakota statute for the crime of passing a bad check. The Court's use of different approaches to interpretation of the eighth amendment can explam, at least in part, these disparate results.

This note analyzes the proper methods of constitutional interpretation of the eighth amendment. After briefly reviewing the conflicting cases, ${ }^{3}$ it examines the main theories of constitutional interpretation. ${ }^{4}$ The note next considers the inetlods of interpretation employed in Rummel and Solem. ${ }^{\text {S It }}$ then examines the inetlod of constitutional interpretation used in a 1910 case, Weems $v$. United States, ${ }^{6}$ and concludes that it represents a better method of realizing the intent of the adopters. ${ }^{7}$ Weems would allow courts freely to decide what is "cruel and unusual," as the eighth amendment's adopters mtended, without the scope of review being bound by narrow historical constraints. ${ }^{8}$

\section{The Two Recent Cases}

A. Ruminel v. Estelle.

Rummel v. Estelle ${ }^{9}$ dealt with an eightl amendment cliallenge to a life sentence under the Texas recidivist statute. ${ }^{10}$ Ruminel had been

\footnotetext{
1. 445 U.S. 263 (1980).

2. 103 S. Ct. 3001 (1983).

3. See infra text accompanying notes 9-30.

4. See infra text accompanying notes 31-49.

5. See infra text accompanying notes 50-74.

6. 217 U.S. 349 (1910).

7. See infra text accompanying notes 84-108.

8. Id.

9. 445 U.S. 263 (1980).

10. Tex. Penal Code AnN. $\S 12.42$ (d) (Vernon 1974).
} 
convicted of credit card fraud ${ }^{11}$ in 1964 and of passing a forged check ${ }^{12}$ in 1969. In 1973 he was convicted of obtaining money by false pretenses ${ }^{13}$ and given a life sentence pursuant to the Texas recidivist statute. ${ }^{14}$ In 1976, "Rummel sought a writ of habeas corpus . . . arguing that life imprisonment was 'grossly disproportionate' to the three felonies that formed the predicate for his sentence and that therefore the sentence violated the ban on cruel and unusual punishments of the Eighth and Fourteenth Amendinents." 15 The district court and the Court of Appeals for the Fifth Circuit rejected Ruminel's claim. ${ }^{16}$ The Supreine Court, by a five-to-four vote, affirmed.17

The Rummel Court, in effect, refused to consider whether the sentence was cruel and unusual. According to the Court, the state decides the length of a prison sentence "subject only to those strictures of the Eighth Amendnient that can be informed by objective factors."18 Invoking the eighth amendment would have been an "extensive intrusion into the basic line-drawing process that is pre-eminently the province of the legislature." 19 The reasoning in Rummel thus foreclosed proportionality review of state prison sentences under the eighth amendment except in extreme cases. ${ }^{20}$

B. Solein v. Helin.

Only three years later, in Solem v. Helm, ${ }^{21}$ the Court faced a situation similar to that in Rummel but arrived at a different result. By
11. 445 U.S. at 265.
12. Id at $265-66$.
13. Id. at 266.
14. Id.
15. Id. at 265 .

16. Rummel v. Estelle, 587 F.2d 651, 662 (5th Cir. 1978) (en banc) ("We do not think that Texas has adopted a system that is cruel and unusual in violation of the eighth amendment, even as applied to William Rummel."), affd, 445 U.S. 265 (1980).

17. 445 U.S. at 264-65. Justice Rehnquist wrote the majority opinion, joined by Justices Burger, Stewart, White and Blackmun. Justice Powell was joined in dissent by Justices Brennan, Marshall and Steveus.

18. Id. at 284. The Court adopted its language about objective factors from Coker v. Georgia, 433 U.S. 584, 592 (1977) (plurality opinion), but went on to reject inplicitly the test used in Coker as too subjective. The Coker plurality considered the penalties imposed for other crimes, the penalties imposed on other convicted rapists, and the penalty carried by the crime of rape in other states. Id. at 593-97. It concluded that "a sentence of death is grossly disproportionate and excessive punishment for the crime of rape and is therefore forbidden by the Eighth Amendment as cruel and unusual punishment." Id. at 592 (footnote omitted).

19. Rummel, 445 U.S. at 275.

20. The Court would allow a legislatively mandated sentence to be reviewed if it were thc death penalty (given the "urique nature" of that punishment), $i d$. at 272 , or a penalty outside of "the Anglo-Saxon system," id. at 275. See, e.g., Weems v. Unitcd States, 217 U.S. 349, 381 (1910) (Philippine punishment cadena temporal consisting of inprisonment, hard labor, and perpetual civil disabilities and limitations on liberty held "cruel and unusual").

2I. 103 S. Cl. 300 (1983). 
1979, Helm, "a 36-year-old man who had spent a good part of the previous 15 years in the state penitentiary," 22 had six felony convictions on his spotted South Dakota record. ${ }^{23}$ Later that year Helm was convicted of passing a bad check, ${ }^{24}$ and given a hife sentence without the possibility of parole under the South Dakota recidivist statute. ${ }^{25}$ Like Ruinmel, Helm sought a writ of habeas corpus, claiming that his sentence was cruel and unusual. ${ }^{26}$ The district court found Rummel dispositive and denied the writ. ${ }^{27}$ The Court of Appeals for the Eighth Circuit reversed, finding Rummel distinguishable. ${ }^{28}$

22. State v. Helm, 287 N.W.2d 497, 499 (S.D. 1980) (Morgan, J., dissenting).

23. In 1964, 1966, and 1969 Helm was convicted of third degree burglary. In 1972 he was convicted of obtaining money under false pretenses. In 1973 he was convicted of grand larceny. In 1975 he was convicted of a third offense of driving while intoxicated. 103 S. Ct. 3001, 3004 (1983).

24. The statute provides:

Any person who, for himself or as an agent or representative of another for present consideration with intent to defraud, passes a check drawn on a financial institution knowing at the time of such passing that he or his principal does not have an account with such financial imstitution, is guilty of a Class 5 Felony.

S.D. CODIFIED LAWS ANN. \$ 22-41-1.2 (1979).

25. The bad check conviction ordinarily would have carried a maximum penalty of five years in prison and a $\$ 5,000$ fine. See S.D. CoDified LAws ANN. \$ 22-6-1(6) (1979). The trial judge mformed Helm that his guilty plea "would trigger the habitual offender statute and that he could be sentenced to hife imprisonment." State v. Helm, 287 N.W.2d 497, 498 (S.D. 1980). Against the advice of his attorney, Helm entered guilty pleas to both charges of the information, adinitting both his guilt in the bad check charge and the fact that he had previously been convicted of six felonies. See Brief for Respondent at 2, Solein v. Helm, 103 S. Ct. 3001 (1983). South Dakota law provides that a "person sentenced to life imprisonment is not ehgible for parole by the board of pardons and paroles." S.D. Codified LAwS ANN. § 24-15-4 (1979).

The trial judge's admittedly stern sentence may have been in reaction to Helm's recalcitrant behavior in court. The "defendant waived his right to a preliminary hearing, insisted on pleading guilty, refused a presentence investigation and demanded immediate sentencing." State v. Helm, 287 N.W.2d 497, 498 (S.D. 1980).

26. Solem, I03 S. Ct. at 3006 . Helm had appealed his sentence to the South Dakota Supreme Court, claiming that it violated the proscription against cruel and unusual punishments found in both the United States Constitution, U.S. Const, annend. VIII, and the South Dakota Constitution, S.D. CoNST. art. VI, § 23. The court affirmed Helm's sentence. State v. Helm, 287 N.W.2d 497, 499 (S.D. 1980). It is interesting to note that the South Dakota Supreme Court, in the past, has been willing under the state constitution to overturn an excessively long sentence "if its duration is so excessive as to 'shock the conscience." Id. at 498 (quotimg State v. Bad Heart Bull, 257 N.W.2d 715, 720 (S.D. 1977)).

27. Solem, 103 S. Ct. at 3006.

28. See Helm v. Solem, 684 F.2d 582, 585-87 (8th Cir. 1982). The court stated:

A life sentence without parole differs quahtatively from a sentence for a term of years or a life sentence with the prospect of parole. As with the death penalty, the State totally rejects rehabilitation as a basic goal of our criminal justice system by imposing a life sentence without parole. Because a life sentence without parole differs in kind from other sentences of inprisonment, the constitutional prohibition against cruel and unusual punishment requires that it bear some relationship to the severity of the underlying crime.

Id. (footnote omitted). 
The Supreme Court, again by a five-to-four vote, affirned the court of appeals by holding that Helm's sentence was "significantly disproportionate to his crime, and [was] therefore prohibited by the Eighth Amendment." 29 In so holding, the Court for the first time reviewed and struck down a prison sentence solely because the length of the sentence was disproportionate to the crime. ${ }^{30}$

\section{CONSTitutional INTERPRETATION OF THE EIgHTH AMENDMENT-A NORMATIVE VIEW}

Whether prison sentences are subject to proportionality review is solely a constitutional question; in both Rummel and Solem the Court had only one law to apply-the eiglth ainendment. ${ }^{31}$ That two sucl disparate holdings emerged from essentially the same Court ${ }^{32}$ only three years apart is symptomatic of the confusion in eiglith amendment jurisprudence. The Court's differing interpretations of the eighth amendment can explaim, at least in part, the disparate results..$^{33}$

Few tools exist to aid a court in deciding cases under the cruel and unusual punishments clause. First, the "legislative history of the Eighth Amendment is not extensive." 34 Second, the words "cruel and unusual" are themselves inherently open-ended. In addition, because of the infrequency with which eiglitl amendinent claims have arisen and because of the often bizarre nature of the few cases which reach the Supreme Court, the judicial gloss on the clause is meager. ${ }^{35}$ These three factors have made the "cruel and unusual" clause an attractive subject for constitutional interpretation. The scholarly literature has

29. Solem, 103 S. Ct. at 3016 (footnote omitted). Justice Powell authored the Court's opinion, joined by Justices Brennan, Marshall, Blackmun, and Stevens. Chief Justice Burger dissented in an opinion jomed by Justices Rehnquist, White and O'Connor.

30. See id. at 3017 (Burger, C.J., dissenting) ("The controlling law in this case is crystal clear, but today the Court blithely disregards any concept of stare decisis.").

31. "Excessive bail shall not be required, nor excessive fines imposed, nor cruel and unusual punishments inflicted." U.S. CoNST. amend. VIII.

32. In the interim between Rummel and Solem, Justice Stewart had stepped down and was replaced by Justice O'Connor. Because Justice Stewart was in the Rummel majority, and Justice O'Connor in the Solem minority, the change in personnel did not affect the outcome. Rather, it was Justice Blackmun's vote which caused the shifting inajority. See supra notes 17, 29.

33. See Solem, 103 S. Ct. at 3016 n.32. In Solem, the Supreme Court, to invalidate Helm's sentence, essentially adopted the view of the court of appeals that the life sentence without parole qualitatively differs from other sentences. See supra note 28 . In reaching the threshold decision to review Helm's sentence, however, the Court rehed on an imterpretation of the eighth amendment that was absent froin the lower court opinion. See id. at 3006-07.

34. Rummel, 445 U.S. at 287 (Powell, J., dissenting).

35. See infra note 76. One unay wonder whether such a thing as "eighth amendment jurisprudence" really exists at all. Through 1968, the clause had "been substantially discussed-either by members of the majority or the dissent on the Court-on only ten occasions." Goldberg \& Dershowitz, Declaring the Death Penalty Unconstitutional, 83 HARv. L. REv. 1773, 1777 (1970). 
given a variety of interpretations to a clause that the Court has not clearly explained. ${ }^{36}$

One normative inethodology of constitutional interpretation, as defined by Paul Brest, is "intentionalism." 37 This approach underlies the Court's constitutional interpretation in the proportionality review cases. ${ }^{38}$ According to Brest, "the intentionalist interprets a provision by ascertaining the intentions of those who adopted it." 39 The intentionalist finds the text of the provision to be "a useful guide to the adopters" intentions," but argues that it "does not enjoy a favored status over other sources." 40

Two different types of intent are encompassed by intentionalism: substantive intent and interpretive intent. ${ }^{41}$ The former refers to an intent to include in the Constitution a certain substantive standard. For example, the adopters of the eighth amendment might have substantively intended that "the language serve only as a sliortliand for the Stuart tortures which were their exemplary applications of the clause."42 Alternatively, they might have intended "to include their exemplary applications and other punishments that they found or would have found equally repugnant." 43 This latter possibility includes an intent "to delegate to future decision-makers the autliority to apply the clause in light of the general principles underlying it." 44 Courts often employ this type of intentionalism as an analytical tool when the adopters' substantive intent is indeterminate. ${ }^{45}$

36. See infra text accompanying notes $37-48$. (1980).

37. Brest, The Misconceived Quest for the Original Understanding, 60 B.U.L. REv. 204, 209

38. For example, both Solem, see infra text accompanying notes $57-66$, and Weems v. United States, 217 U.S. 349 (1910), see infra text accoinpanying notes 84-108, considered at length the intended scope of the eighth amendment.

39. Brest, supra note 37, at 209. Brest does not deem intentionalism the best methodology of constitutional interpretation. He suggests that the imtentionalist inay "be questing after a chimera." Id. at 222.

40. Id. at 209. The other sources available to the intentionalist are historical material, $i d$. at 218-22, and the "inference from structure and relationship" within the Constitution, $i d$. at 217-18.

41. Brest distimguishes between

(1) the adopters' interpretive imtent and the imtended scope of a provision and (2) their substantive intent concerning the application of the provision. . . . To be a coherent theory of interpretation, intentionahisin must distinguish between the adopters' personal views about an issue and their intentions concerning its constitutional resolution. And it is only by reference to their imterpretive intent and the imtended scope of a provision that this distimction can be drawn.

Id. at 220 (emphasis in original).

42. Id. at 216.

43. $I d$.

44. $I d$.

45. See, e.g., id. 
Working from similar principles of imterpretive intent, Ronald Dworkin suggests a somewhat different way to look at the adopters' intent. He argues that a court inust look at the general principles of "cruel and unusual" (the "concept") in order to determine its own "conception" of cruelty. ${ }^{46}$ Dworkin argues that a court "can enforce what the Constitution says only by making up its mind about what is cruel." $47 \mathrm{He}$ recognizes that im some cases the conclusion of the court may differ from the original substantive intent of the adopters. In Brest's words, "the adopters may have intended that their own views not always govern." 48

Because substantive intent may differ from interpretive intent, the methodology chosen by the Court to interpret the eighth amendinent can determine the outcome of a case. Cases involving proportionahity review of sentences are no exception. With the unsettled state of the law-first prohibiting and then permitting proportionality review of sentences-it is likely that the same or related questions will arise in the near future. ${ }^{49}$ Determining the proper answer under such circumstances will mevitably mvolve choosing the best interpretive methodology. Thus, a critical analysis of the Supreine Court's inethodology in Rummel and Solem is in order.

\section{The Supreme Court's Constitutional Interpretive Methodology}

A. Rummel v. Estelle.

The opinion of the Court in Rummel v. Estelle ${ }^{50}$ lacks any explicit constitutional imterpretation. Justice Rehnquist, writing for the Court, made no mention of the history of the eighth ainendinent, the intentions of the adopters, or even the text of the amendment. Instead, the Court rehed on precedent froin other Supreine Court decisions concerning the reach of the cruel and unusual punishments clause. Possibly, by relying on precedents, the Court incorporated the underlying imterpretations of the eighth annendment found in those cases. ${ }^{51}$ The

46. R. Dworkin, Taking Rights Seriously 135 (1977).

47. Id.

48. Brest, supra note 37 , at 216 . "The adopters may have understood that . . f further thought by themselves or others committed to [the] underlying principle might lead them to change their minds." Id.

49. Proportionality, especially in death cases, is a topic of much moment. See, e.g., Pulley v. Harris, 104 S. Ct. 871, 879-80 (1984) (holding state proportionality review of capital cases not required).

50. 445 U.S. 263 (1980).

51. The Rummel Court used three types of authority to argue that Rummel's sentence could not be reviewed under the cruel and unusual punishments clause. First, it adopted the statement 
Court, however, made no explicit endorsement of the constitutional imterpretation in any particular case that it used as precedent, and made no response to the historical and interpretive segments of the dissenting opinion. 52

The Rummel Court appears to have rejected an interpretation of the eighth amendment that finds an interpretive intent on the part of the adopters to give the Court the freedom to formulate its own conccption of the cruel and unusual punishments clause:

Perhaps ... "time works changes" upon the Eighth Amendment, bringing into existence "new conditions and purposes." We all, of course, would like to think that we are "moving down the road toward human decency." Within the confines of this judicial proceeding, however, we have no way of knowing which direction that road lies. Penologists themselves have been unable to agree whether sentences should be light or heavy, discretionary or determinate. ${ }^{53}$

By refusing to determine whether Rummel's sentence was crucl and unusual, ${ }^{54}$ the Court may have embraced iniphicitly the idea that the adopters of the eighth ainendment had only a substantive intent, and that their substantive intent did not entbrace a prohibition of disproportionate prison sentences. According to the Rummel Court, the determination whether a sentence violates the eighth amendment is only to be made in the most extreine circumstances"s because "the length of the sentence actually imposed is purely a matter of legislative prerogative." 56

The suggestion that the Court implicitly rejected interpretive intent rests upon the assumption that if the Court had substituted its own conception of "cruel and unusual" for the substantive views of the framers, it would have reviewed the sentence as possibly disproportion-

from Coker v. Georgia, 443 U.S. 584, 592 (1977), that proportionality challenges must be informed by "objective factors" or fail. See supra notes $18-19$ and accompanying text. Second, it claracterized the death-penalty cases and Weems as affording the proper objective criteria to allow a bright line to be drawn. See supra note 20. Third, it claracterized the factually-related cases of Badders v. United States, 240 U.S. 391 (1916), and Graham v. West Virginia, 224 U.S. 616 (1912), as lacking the requisite objective criteria. It thus refused to draw a line between proportionate and disproportionate pumshments. See Rummel, 445 U.S. at 272-77.

52. See Rummel, 445 U.S. at 287-93 (Powell, J., dissenting).

53. Id. at 283 (citations omitted). Thus, the Court refused to apply its own "conception" of cruel and unusual. Cf. supra text accompanying note 46 (contention that court should apply its own conception).

54. See Rummel, 445 U.S. at 284-85; see also supra text accompanying notes 18-20.

55. See supra note 20 and accompanying text.

56. Rummel, 445 U.S. at 274 (footnote omitted). But see infra text accompanying notes 10408. Calling the prison sentence a matter of legislative prerogative is not convincing in the face of an explicit constitutional constraint, see infra text accompanymg notes 104-08, an argument the Rummel Court did not even take mto account. 
ate. Even if that assumption is true, the Court's lack of analysis regarding the mtent of the adopters suggests that the ultimate holding was the product of the Court's feeling that the sentence itself actually was not cruel and unusual-a notion that obviously conflicts with the rejection of the interpretive intent inethodology. If the assumption is false, then it is impossible to know what methodology the Court employed. In any event, the lack of discussion concerning the eighth amendment renders the case of little value in selecting future interpretive methodologies.

\section{B. Solem v. Helm.}

In contrast to the Rummel decision, the Solem Court explored in detail the history of the eighth amendinent to try to determine the scope intended by the adopters. According to the Court, the "principle of proportionahty" 57 was part of early Enghish common law. The Court noted that the Magna Charta, ${ }^{58}$ and the First Statute of Westminister, which stated that one's fines should be "according to the quantity of his trespass," 59 expressed the principle. The Solem Court went on to enumerate instances in which common law courts used these guarantees "to invalidate disproportionate punishments," including prison sentences. ${ }^{60}$

According to the Court, when the English Bill of Rights was drafted, it "repeated the principle of proportionality" 61 or "at least incorporated 'the longstanding principle of Enghish law that the punishment . . . should not be, by reason of its excessive length or severity, greatly disproportionate to the offense charged.' "62 Because the framers of the eighth amendment adopted, alınost verbatim, the language of the English Bill of Rights, ${ }^{63}$ and because "one of the consistent themes

57. Solem, 103 S. Ct. at 3007.

58. "[T]hree chapters of Magna Charta were devoted to the rule that 'amercements' may not be excessive." Id. at 3006 (footnotes omitted). The Court added that an "amercement was similar to a modern-day fine." Id. at n.8.

59. First Statute of Westminster, 1275, 3 Edw. 1, ch. 6.

60. Solem, $103 \mathrm{~S}$. Ct. at 3007; see, e.g., Hodges v. Humkin, 2 Bulst. 139, 140, 80 Eng. Rep. 1015,1016 (K.B. 1615) ("imprisonment ought always to be according to the quality of the offense").

61. Solem, $103 \mathrm{~S}$. Ct. at 3007 . English law provided that "excessive Baile ought not to be required nor excessive fines imposed nor crnell and unusual punishments inflicted." Bill of Rights, 1689, W. \& M., ch. 2. For an examination of the historical background of the provision, see generally Granucci, "Nor Cruel and Unusual Punishments Inflicted:" The Original Meaning, 57 Calif. L. Rev. 839, 846-60 (1969).

62. Solem, 103 S. Ct. at 3007 (quoting R. Perry, Sources of Our Liberties 236 (1959)); see also $4 \mathrm{~W}$. BLACKSTONE, COMmentaries * $16-19$ (general condemnation of excessive punishments).

63. Compare supra note 31 with supra note 61 . 
of the era was that Americans had all the rights of English subjects"64 and that "our Bill of Rights was designed in part to ensure that these rights were preserved," 65 the Solem Court concluded that the adopters" "use of the language of the Englisl Bill of Rights is convincing proof that they intended to provide at least the same protection-including the right to be free from excessive punishments." 66 Thus, the Solem Court imputed to the adopters of the eighth ainendment an intent that allows the amendment to encompass any punishment at common law that is excessive.

The Solem Court may have gone far enough in its analysis of the adopters' intent to allow it to review and invalidate Helm's sentence. ${ }^{67}$ By interpretimg the eiglth amendment as a prohibition against excessive punishments, and concentratimg on the common law punishments to which the doctrine was applied, the Court discovered broad substantive intent: the adopters intended to prohibit not only certain inhumane methods 68 of punishment, but also meant to prolibit pumshments that were recognized at common law as generally acceptable, but which nay sometimes become unconstitutional because excessive. ${ }^{69}$

It may be argued, however, that by delimeating the substantive imtent of the adopters, the Court has cut off eighth amendment review of any punishments not based on the inhumanity of its method of punishment or its length. ${ }^{70}$ It is conceivable that punishments not known at common law are not reviewable under the imterpretation of the adopt-

64. Solem, 103 S. Ct. at 3007.

65. Id.

66. Id. By adding the words "at least" the Court seems to be adding a caveat that the rights nnder the Aunerican Bill of Rights are not necessarily coterminous with rights under the Englislt Bill of Rights. The Court reiterates that caveat when it states that "no penalty is per se constitutional." Id. at 3009-10.

67. By failing to overrule Rummel, the Solem Court has only invalidated Helm's "penultinate sentence," i.e., life imprisonment with no possibility of parole. In explicitly refnsing to overrule Rummel, see id. at $3008 \mathrm{n} .13,3016 \mathrm{n} .32$, the Solem Court, in essence, has foreclosed review of a Rummel-like situation, regardless of the intent of the adopters.

68. See id. at 3006. But cf. Granucci, supra note 61, at 859 ("no prohibition on methods of punishment was intended").

69. See Solem, $103 \mathrm{~S}$. Ct. at 3006.

70. One punishment that conceivably could not be reached under the Solem approach to the eighth amendinent is the punishment addressed by the Court in Trop v. Dulles, 356 U.S. 86 (1958). The Court there confronted a punishment not only unknown during the reign of the Stuarts, but also not inflicted upon the body. It declared that the Nationality Act of 1940 , $\S 401(\mathrm{~g}), 54$ Stat. $1168,1168-69$ (codified at 8 U.S.C. $\$ 801(\mathrm{~g})(1946)$ ), whicls provided that a citizen "shall lose his nationality" if he is convicted of desertion during wartime, inflicted a cruel and unusual pumishment "more primitive than torture." Trop, 356 U.S. at 101. 
ers' intent set forth in Solem. ${ }^{71}$ In addition, under the Solem standard, a court might be held incompetent to review punishments for acts at common law generally considered not criminal, but for which the legislature has imposed criminal sanctions. ${ }^{72}$ However that may be, a sentence like Rummel's apparently cannot be reviewed under the Solem standard, as the holding in the Rummel case has not been overruled. ${ }^{73}$ Although the Solem Court did not necessarily need to reach the issue of the ultimate scope of the eighth amendment, it appears to have accepted the substantive intent of the adopters as the measure of the scope of the amendment; however, an examination of the adopters' interpretive mtent $^{74}$ may lead to a different understanding of the eighth amendment's scope. The question remams: did the Court read the eighth amendment as broadly as the adopters actually intended?

\section{WEEMS V. UNITED STATES AND THE ADOPTERS' INTENT}

In 1910, in Weems v. United States, ${ }^{75}$ the Supreme Court for the first time undertook a comprehensive discussion of the eighth amendment, including the intent of the adopters. ${ }^{76}$ Unlike the later opinions in Rummel and Solem, the Weems opimion analyzes the interpretive in-

71. A static substantive interpretation of the eighth aunendinent has a tendency to lead to an emasculated and eventually hollow guarantee against cruel and unusual punishments. See infra text accompanying notes 102-03. The danger becoines particularly poignant when the methods of inflicting cruel and unusual punishments do not remain static, but instead evolve into more subtle and technologically proficient means. See, e.g., Louisiana ex rel. Francis v. Resweber, 329 U.S. 459, 463-64 (1947) (unsuccessful eighth ainendment challenge to state's attempt to eleetrocute convict a second time after first electrocution failed).

72. Cf. Robinson v. California, 370 U.S. 660, 667 (1962) (striking down, under the eighth amendment, state law making narcotics addiction a crime).

73. See supra note 67.

74. See infra text accompanying notes 84-108.

75. 217 U.S. 349 (1910).

76. The Supreme Court had few opportunities to discuss the scope of the eighth amendment, see supra note 35, prior to the incorporation of the eighth amendinent into the fourteenth ainendment in Robinson v. Califoruia, 370 U.S. 660, 667 (1962). Historical circuinstances worked against a broad reading of the eighth amendment. Because the Court dechned to apply the amendmeut to punishments mandated by the states until 1962, the discussion of the amendment was limited to its apphication in the context of federal crimes. The scope of federal crimes was itself fairly narrow because the "federal courts have no criminal jurisdiction by virtue of the common law ex proprio vigore, and can exercise such jurisdiction only as is exprcssly conferred upon thein by Congress." J. Miller, HaNDBOOK of CRIMINAL Law 529 (1934). Federal crimes generally either were not serious enough or did not occur with sufficient frequency to create a body of eighth amendment authority. $C$. id. at 530-31 (enumeration of federal crimes). Given the rarity of criminal litigation in the federal courts and the Supreine Court's unwillingness to entertain petitions for habeas corpus arising from the states, it is uot surprising that the Court had little opportunity to address the eighth amendinent until 1910. The Weems case arose in a territory administered by the federal governmeut-the Philippine Islands. See Weems, 217 U.S. at 357. 
tent of the adopters. ${ }^{77}$

\section{A. Weems v. United States: Background.}

Weems, a disbursing officer of the Bureau of Coast Guard and Transportation of the United States Government of the Philippime Islands, was convicted of falsifying a public and official document. ${ }^{78}$ Under the Philippime Penal Code, ${ }^{79}$ the mandatory penalty was cadena temporal, a punishment that imcluded imprisonment, hard and painful labor, complete and perpetual civil disability, and perpetual limitations on liberty. ${ }^{80}$ The case arose on a writ of error from the Supreme Court of the Philippimes. ${ }^{81}$ The United States Supreme Court held Weem's penalty of cadena temporal to be "cruel in its excess of imprisonment and that which accompanies and follows imprisonment . . . [and] unusual in its character." 82 The Court concluded by findimg the penalty "repugnant to the bill of riglits." 83

\section{B. Weems v. United States: Constitutional Interpretation.}

1. Examination of the Adopters' Possible Substantive Intent. The method of constitutional interpretation, and the intent imputed to the adopters, is much broader in Weems than in Solem. The Weems Court began its analysis by considering the substantive scope intended by the adopters-specifically, their own definition of "cruel and unusual." Until Weems, no case liad arisen which had "called for an exhaustive definition" 84 and the Court noted that "[w]hat constitutes cruel and un-

77. Trop v. Dulles, 356 U.S. 86 (1958) is the only case to follow completely the Weems reasoning concerning the interpretive intent of the adopters. See supra note 70.

78. See Weems, 217 U.S. at 357-58. The crime required no criminal intent, as punishment was called for "though there be no one imjured, though there be no fraud or purpose of it, no gain or desire of it." Id. at 365.

79. The Phillipine punishment borrowed from Spanish law. See Weems, 217 U.S. at 363.

80. The Court described this penalty:

Its minuinuin degree is confinement in a penal institution for twelve years and one day, a chain at the ankle and wrist of the offender, hard and painful labor, and no assistance from friend or relative, no marital authority or parental rights or rights of property, no participation even in the family council. These parts of the penalty endure for the term of imprisonment. From other parts there is no intermission. His prison bars and chains are removed, it is true, after twelve years, but he goes from them to a perpetual limitation of his hiberty. He is forever kept under shadow of the crime, forever kept within voice and view of the criminal nagistrate, not being able to change his domicil without giving notice to the "authority immediately in charge of his surveillance," and without permission in writing.

Id. at 366 .

81. See id. at 357.

82. Id. at 377.

83. Id. at 382 .

84. Id. at 369. 
usual punishment has not been exactly decided." 85 The legislative history of the enactment of the eighth amendment mdicated "very little debate in Congress" concerning the precise meaning of the provision. ${ }^{86}$ The Weems Court did note that Representative Snith of South Carolina " "objected to the words "nor cruel and unusual punishment;" the import of them being too indefinite." "87 Acknowledging the lack of precise guidelines for interpreting the clause, the Court cited with approval its earlier statentent in Wilkerson $v$. Utah" that " "[d]ifficulty would attend the effort to define witl exactness the extent of the constitutional provision which provides that cruel and unusual punishments shall not be inflicted.' "89 The Court accordingly undertook no exact or exhaustive definition of "cruel and unusual" and rejected the concept of a precise substantive scope because the adopters' understanding was itself too indeterminate. Anticipating the normative methodology outlined by Brest, ${ }^{90}$ the Court then looked to the interpretive intent of the adopters, namely, to the general primciples underlying the clause and the autliority delegated by the adopters to future decisionmakers. ${ }^{91}$

2. Examination of the Adopters' Interpretive Intent: The Spirit of the Adopters. Attempting to unlock the interpretive intent of the adopters, the Weems Court found a key in the spirit that animated the adoption of the Bill of Rights. By looking at the "experience of evils"92 in light of which the Bill of Rights was enacted, the Court sought to understand how the adopters intended future interpreters to construe the provision.

The Court rejected the argunient suggested by Justice Story that the clause was "adopted as an admonition to all departments of the national governinent, to warn them against such violent proceedings as lias [sic] taken place in England in the arbitrary reigns of some of the

85. Id. at 368 . The Court meutioned one state court decision that a prison term might fall within the definition of "cruel and unusual," $i d$. (citing McDonald v. Commonwealth, 173 Mass. 322, 53 N.E. 874 (1899)), and observed that "[o]ther cases have selected certain tyrannical acts of the Euglish monarchs as illustrating the meaning of the clause and the extent of its prohibition." Weems, 217 U.S. at 368.

86. Weems, 217 U.S. at 368.

87. Id. at 368-69 (quoting 2 CONG. REG. 225 (1789), reprinted in 1 ANNALs of CoNG. 754 (J. Gales ed. 1789)).

88. 99 U.S. 130 (1878).

89. Weems, 217 U.S. at 370 (quoting Wilkerson, 99 U.S. at 135-36).

90. See supra text accompanying notes $37-48$.

91. See supra text accoinpanying notes $44-48$.

92. Weems, 217 U.S. at 373. The Court rejected the idea that the amendmeut was enacted inerely out of a fear "of the forms of abuse that went out of practice with the Stuarts." Id. at 372. Brest refers to the inotivating experieuces of the adopters as "their exeinplary applications of the clause." Brest, supra note 37, at 216 . 
Stuarts."93 The Court saw in the provision more than a merely symbolic warning agaimst Stuart abuses. Instead, the Court focused on two paradigmatic figures in the constitutional conventions, one an opponent of the Bill of Rights, the other a supporter, in order to analyze the conflicting concerns surrounding adoption of the eighth amendment.

The Weems Court viewed "Mr. Wilson in the Pennsylvania convention"94 as the paradigmatic figure for those opposed to the eighth amendment. According to the Court, Wilson "considered that it was unnecessary, and had been purposely omitted from the Constitution. ... Wilson, and those who thought like Wilson, felt that its ideals would be represented, not debased, by legislation."9s In Wilson's view, therefore, the legislature in a democratic society could be expected never to mandate a pumishinent that would fall within the ban of the amendment. In the words of Justice Story, the eighth amendment "would seem to be wholly unnecessary in a free government, smce it is scarcely possible that any department of such a government should authorize or justify such atrocious conduct."96

The Weems Court, however, found quite different fears and concerns motivating the supporters of the Bill of Rights-and noted that it was the supporters who ultimately prevailed. The Court considered Patrick Henry the paradigm for those who favored adoption of the eighth amendment. According to the Court, "Henry and those who believed like him would take no chances." 97 They were animated by a "predominant pohtical impulse" of "distrust of power, and they imsisted on constitutional limitations agamst its abuse."98 The Court concluded that the adopters "surely . . . intended more than to register a fear of the forms of abuse that went out of practice with the Stuarts. . . . [T]heir jealousy of power had a saner justification than that."99 As did the adopters, the Court queried: "With power in a legislature great, if not unlimited, to give criminal character to the actions of men, with power unlimited to fix terms of imprisonment with what accompaniments they might, what more potent imstrument of cruelty could be put into the hands of power?"100 That a democratically

93. Weems, 217 U.S. at 371 (quoting 2 J. StORY, COMMENTARIES ON THE CONSTITUTION OF THE UNITED STATES § 1903 (5th ed. 1891)).

94. Weems, 217 U.S. at 372.

95. Id.

96. Id. at 371 (quoting 2 J. STORY, supra note 93, § 1903).

97. Weems, 217 U.S. at 372 . Henry was in the Virginia Conveution. Id.

98. Id.

99. Id.

100. Id. at $372-73$. 
elected legislature would define crimes and mandate their punishments provided no consolation to the adopters of the eighth amendment.

Having ascertained the inotivations of the adopters of the eighth amendment, the Court went on to discuss their interpretive intent. The Weems Court attributed "an intelligent providence to its advocates." 101 Indeed, "it inust have coine to them that there could be exercises of cruelty by laws other than those which inflicted bodily pain or unutilation."102 The Court articulated a broad interpretive intent for the eighth amendment:

Time works changes, brings into existence new conditions and purposes. Therefore a principle to be vital inust be capable of wider application than the mischief which gave it birth. This is particularly true of constitutions. They are not eplieineral enactınents, designed to meet passing occasions. They are, to the words of Chief Justice Marshall, "designed to approacli immortality as nearly as human institutions can approach it." The future is their care and provision for events of good and bad tendencies of which no prophecy can be made. In the application of a constitution, therefore, our conteinplation cannot be only of what has been but of what may be. Under any other rule a constitution would be deficient in efficacy and power. Its general principles would have little value and be converted by precedent into impotent and lifeless formulas. Rights declared in words might be lost in reality. ${ }^{103}$

The Weems Court found in the intent of the adopters of the eighth amendment a constitutional mandate to the judiciary to give "efficacy and power" to the provision by deciding for itself what is cruel and unusual. ${ }^{104}$ Observing that "the ineaning and vitahty of the Constitution have developed against narrow and restrictive construction," 10 the Court rejected the contention that the clause "had ceased to be a restraint upon legislatures." 106 It conceded that the legislature has a general power "to define crimes and their punishments," 107 but stressed that the inquiry must not end there:

We disclaim the right to assert a judgment against that of the legislature of the expediency of the laws or the right to oppose the judicial

101. Id. at 373.

102. Id.

103. Id. (quoting Cohens v. Virginia, 19 U.S. (6 Wheat.) 264, 387 (1821).

104. See Dworkin, supra note 46, at 134-35; see also infra text accompanying note 108.

105. See Weems, 217 U.S. at 373 . The Court gave as exanples the broad interpretations it had given to the fourteenth amendment, the commerce power and, the prohibition of ex post facto laws. Id. at 373-74.

106. Id. at 376. The view of the supporters of the Bill of Rights, which the Court impnted to Patrick Henry, supra text accompanyimg notes 98-100, seems not to comport with this grant of discretion to the legislature. Rummel also appears to conflict with this view. See supra text acconpanying notes $18-20$.

107. Weems, 217 U.S. at 378. 
power to the legislative power to define crimes and fix their punishment, unless that power encounters in its exercise a constitutional prohibition. . . . [T] he legislatures have no limitation . . . but constitutional ones, and what those are the judiciary must judge. ${ }^{108}$

\section{The Consequences of Employing the WeEMS INTERPRETIVe METHODOLOGY}

After finding a broad interpretive intent on the part of the adopters, the Weems Court einployed a test similar to the one used in So$\mathrm{lem}^{109}$ to invalidate the punishment. Although the results in the two cases are the saine, the examination of the adopters' intent is nore comprehensive and the intent imputed to the adopters is broader in Weems than in Solem. Instead of looking simply at the punishments historically coinprehended by the words of the eighth ainendment, the Weems opinion goes further, examining the attitudes that motivated the adopters of the Bill of Rights and undertaking a discussion of why such constitutional provisions were ineant to be construed broadly. Thus, under the Weems interpretation, a court need not look "backwards for examples by which to fix the ineaning of the clause." 110

Unlike the Rummel Court, the Weems Court did not balk at overturning a legislatively mandated sentence. Whereas the Rummel Court refused to overturn the state nandated sentence because of the diffculty of judging what is cruel and unusual, the Weems Court, faced with the constitutional mandate of the adopters of the eighth amendment, did not hesitate to overturn the sentence. The eighth amendment under the Weems view is relevant to any punishment inandated by legislatures, and to any decision on their part to characterize particular conduct as criminal. ${ }^{111}$ Instead of adopting the narrow historical method utilized by the Solem Court, the Weems Court anticipated methodologies later suggested by Brest and Dworkin.

\section{Conclusion}

The Rummel Court held, without examination of the adopters' imtent, that eighth amendinent review was limited to the inost outrageous punishments. The Solem Court examined the historical roots of the amendment, but failed to overrule Rummel, thereby limiting its proportionality review to the particular punshment iniposed in that case-life imprisonment without the possibility of parole.

108. Id at 378,379 (emphasis added).

109. Compare id. at 380-82 with Solem, $103 \mathrm{~S}$. Ct. at 3002-16.

110. Weems, 217 U.S. at 377.

111. See supra text accompanying note 100 . 
The interpretive methodology employed by the Weems Court is superior to that of either of the two recent cases. The Weems opinion, using the full range of historical material and interpretive methods, deinonstrates a more sophisticated reading of the Bill of Rights. Under the Weems view, the judiciary's mandate to examine the actions of the legislature derives from a clause that is "progressive, and is not fastened to the obsolete but may acquire ineaning as public opinion becomes enlightened by humane justice."112 By refusing to limit the clause to review of only the most egregious and draconian of penalties, ${ }^{113}$ or of the most limited range of legislative decisions, ${ }^{114}$ the Weems Court arrived at a position that makes the eighth ainendment an important check on legislative power.

Pressly Millen

112. Weems, 217 U.S. at 378.

113. See supra text accompanying note 20.

114. See supra note 67. 